\title{
A synthetic and NMR conformational study of spiro cyclic quaternary ammonium salts
}

\author{
R. Alan Aitken, ${ }^{*}$ Eilidh F. Philp, Frank G. Riddell,* and Melanja H. Smith \\ School of Chemistry ,University of St Andrews, North Haugh, \\ St Andrews, Fife, KY16 9ST, UK \\ E-mail: raa@st-and.ac.uk
}

\section{Dedicated to our good friend Douglas Lloyd to mark the occasion of his $\mathbf{8 0}^{\text {th }}$ birthday}

\begin{abstract}
The preparation and NMR spectra for a range of spirocyclic mono-, bis- and tris-quaternary ammonium salts are reported. In the case of the tricyclic bis(ammonium)salt 7 a dynamic process is observed in the ${ }^{13} \mathrm{C}$ NMR spectrum and by means of a variable temperature study and MAS solid state NMR this isattributed to ring-inversion of central ring with the axial and equatorial C$\mathrm{N}^{+}$carbons of the outer two rings being non-equivalent. The energy barrier for this inversion is determined to be $53.4 \pm 0.2 \mathrm{~kJ} \mathrm{~mol}^{-1}$.
\end{abstract}

\section{Introduction}

In the context of designing organic templates of novel geometry for the formation of new zeolite structures, one of us has recently been interested in synthesis of bis- and tris-quaternary ammonium salts with a variety of two and three dimensional structures. In particular, the tristriethyl ammonium salt 1 was found to give a new microporous material designated STA-5 while the corresponding tris-quinuclidinium salt 2 gave the known structure STA-1. In this paper we describe the synthesis of a range of mono-, bis- and tris-quaternary ammonium salts with spirocyclic structures.

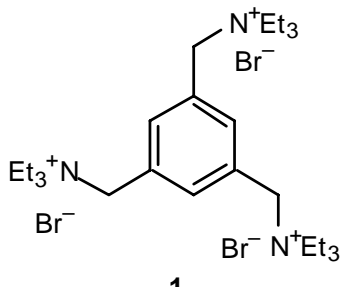

1

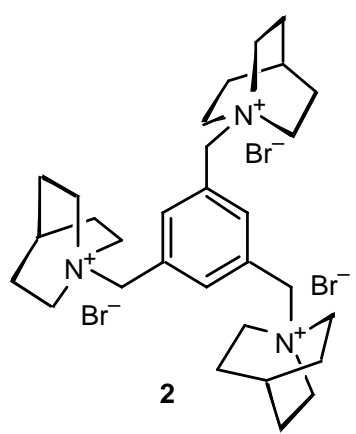




\section{Results and Discussion}

The series of spirobicyclic salts 3-6 were all described in 1954 by Blicke and Hotelling in a series of papers where they were evaluated as novel cholinergic agents for the control of blood pressure. Because of the early date of this work, no NMR data exist for these interesting structures and these are reported here.

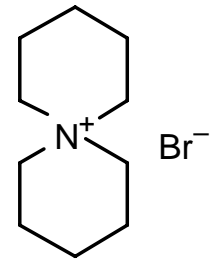

3

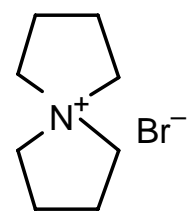

4

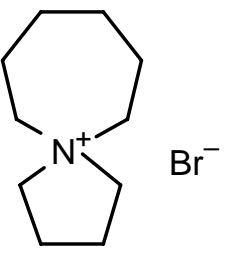

5

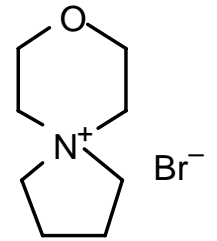

6

The compounds were prepared by a modification of the published method, although some variation in the work-up procedure was required to obtain them in pure form free of inorganic salts. A mixture of the appropriate $\alpha, \omega$-dibromoalkane and $1 \mathrm{M}$ aqueous sodium hydroxide was heated under reflux while the appropriate cyclic amine (1 equiv.) was added dropwise. After there action the products were separated by addition of strong (10 M) sodium hydroxide solution and purified as described in the experimental section. Using piperidine/dibromopentane gave 3 while $\mathbf{4}$ was obtained from pyrrolidine/dibromobutane, $\mathbf{5}$ from pyrrolidine/dibromohexane, and $\mathbf{6}$ from morpholine/dibromobutane. The products were all found to be highly hygroscopic and turned oily after storage for a few days. Their ${ }^{1} \mathrm{H}$ and ${ }^{13} \mathrm{C}$ NMR spectra formed a consistent pattern with signals for the carbons adjacent to $\mathrm{N}^{+}$in the range $\delta_{\mathrm{C}} 60-66$.

The published route to the dispirotricyclic salt 7 involves formation of 1,2di(piperidino)ethane and its subsequent cyclisation with 1,2-dibromoethane. ${ }^{3}$ Instead of this we used a more direct route: reaction of piperazine with 2 equivalents of 1,5-dibromopentane in the presence of sodium hydroxide, which gave the desired product in one step in acceptable yield. Although the original preparation of 7 was prior to the advent of NMR spectroscopy, a more recent paper does give a low frequency ${ }^{1} \mathrm{H}$ spectrum. While the proton spectrum observed here was in good agreement with this and the patterns established for 3-6, the ${ }^{13} \mathrm{C}$ NMR spectrum immediately revealed an unexpected phenomenon: at room temperature there appeared to be only three signals as compared to the four expected. 

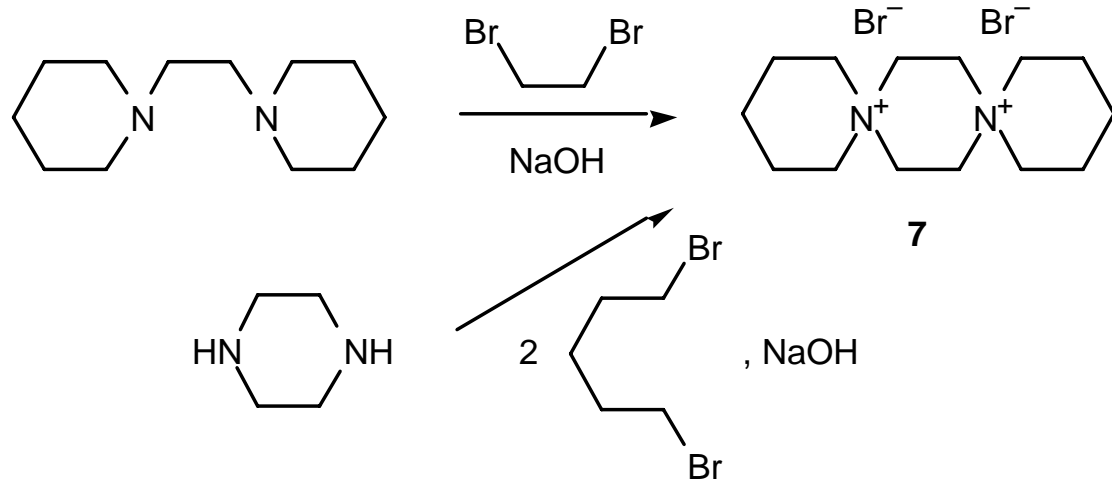

7

Careful examination of the spectrum did however reveal an extremely broad signal at $\delta_{\mathrm{C}} 64.0$ suggesting that a dynamic process on the NMR time-scale might be involved associated with coalescence of this signal near to room temperature. This was readily confirmed by means of a variable temperature NMR study. For this a suitable solvent had to be chosen and since the salt was completely insoluble in $\mathrm{d}_{4}$-methanol, a 2:1 mixture of $\mathrm{D}_{2} \mathrm{O}$ and $\mathrm{CD}_{3} \mathrm{OD}$ proved to be suitable allowing good solubility for 7 and allowing spectra to be obtained down to $-20^{\circ} \mathrm{C}$. At this temperature the signal of interest had been replaced by two separate equal sized signals at $\delta_{\mathrm{C}}$ 66.85 and 56.67. As the temperature was raised these were observed to broaden and coalesce to give, at $+50^{\circ} \mathrm{C}$ a single signal at $\delta_{\mathrm{C}} 62.1$. The coalescence temperature was determined to be +19 $\pm 1^{\circ} \mathrm{C}$ corresponding to a value of $\Delta \mathrm{G}^{\#}$ of $53.4 \pm 0.2 \mathrm{~kJ} \mathrm{~mol}{ }^{-1}$ for the process.

The question now arises as to the origin of the observed process. Assuming that all the sixmembered rings are present as chairs two conformations are available for $\mathbf{7}$ differing in the state of ring inversion of one of the terminal piperidium rings. One 7a possesses a $\mathrm{C}_{2}$ axis passing perpendicular to the average plane of the central piperazinium ring. The other $7 \mathbf{b}$ possesses a $\mathrm{C}_{2}$ axis passing through the midpoints of the $\mathrm{C}-\mathrm{C}$ bonds in the central piperazinium ring. The solid state NMR spectra and the solution state NMR spectra suggest that only one of these is appreciably populated at around and below ambient temperature. We would suggest that this may well be 7 a.

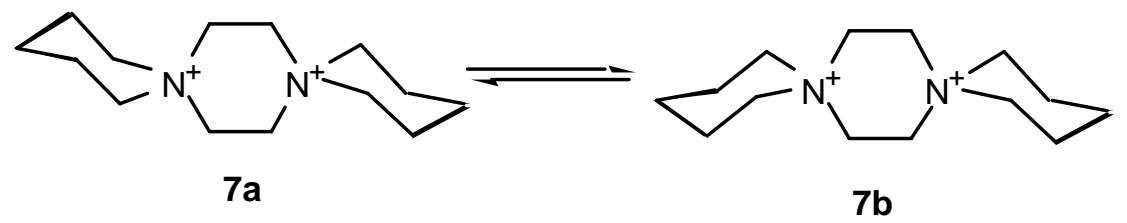

Slowing inversion of the central ring would lead to a coalescence of the outer ring carbons. Slowing of the inversion of the outer rings would lead to a coalescence of the central ring carbons. This may be seen clearly in the structures below where the carbon atoms of the noninverting $\operatorname{ring}(\mathrm{s})$ marked $\bullet$ are initially axial with respect to the inverting ring(s), but as a result of the inversion process they become equatorial. 


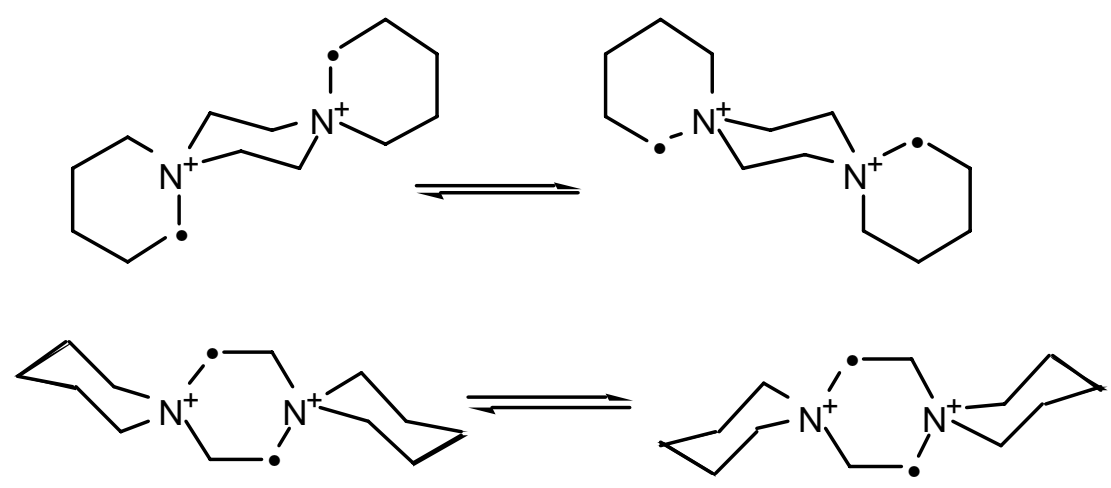

A $2 \mathrm{D}{ }^{1} \mathrm{H}^{-13} \mathrm{C}$ heteronuclear correlation experiment at $+60^{\circ} \mathrm{C}$ associated the coalescing ${ }^{13} \mathrm{C}$ resonance at $62.1 \mathrm{ppm}$ with the ${ }^{1} \mathrm{H}$ triplet at $3.69 \mathrm{ppm}$. The non-coalescing resonance at 54.1 ppm is associated with the ${ }^{1} \mathrm{H}$ singlet at $3.98 \mathrm{ppm}$. In the case of rapid inversion of both rings (as at $+60^{\circ} \mathrm{C}$ ) the piperazinium ${ }^{1} \mathrm{H}$ resonance is expected to be a singlet and the piperidium ${ }^{1} \mathrm{H}$ resonances to be multiplets. Thus the $2 \mathrm{D}$ spectrum unequivocally assigns the ${ }^{13} \mathrm{C}$ resonances and associates the observed process with inversion of the central piperazine ring. The observed barrier is satisfyingly similar to the value reported for the ring inversion barrier in $N, N, N^{\prime}, N^{\prime}-$ tetramethylpiperazium bromide measured in $\mathrm{SO}_{2}$ solution $\left(53.9 \mathrm{~kJ} \mathrm{~mole}^{-1}\right)$.

The solid-state ${ }^{13} \mathrm{C}$ CP-MAS NMR spectrum of 7 shows three signals for the $\mathrm{CH}_{2} \mathrm{~N}$ region at $\delta_{\mathrm{C}} 62.4,55.6$ and $47.6 \mathrm{ppm}$ in the approximate intergrated intensity ratio of 1:2:1. This is consistent with either $7 \mathbf{a}$ or $\mathbf{7 b}$ and slow ring inversion in the solid, with an accidental equivalence of two $\mathrm{C}$ resonances.

It is interesting to note that, in the solution spectrum of 7 at $-20^{\circ} \mathrm{C}$ in which separate sharp signals were observed for the $\mathrm{N}^{+}-\mathrm{C}$ atoms of the outer rings, there was considerable broadening of the signal at $\delta_{\mathrm{C}} 52.5$ corresponding to the four $\mathrm{N}^{+}-\mathrm{C}$ carbons of the central ring. This clearly points to the occurrence of a lower energy dynamic process involving ring-inversion of the outer rings such as that described above but, since lower temperatures could not be reached in the solvent being used, this could not be investigated further.

A range of spirocyclic tris(ammonium)salts were also prepared modelled on the salt $\mathbf{8}$ which was prepared by reaction of hexa(bromomethyl)benzene 9 with dimethylamine, and subsequently shown to be an effective template for formation of zeolite ZSM-18. 


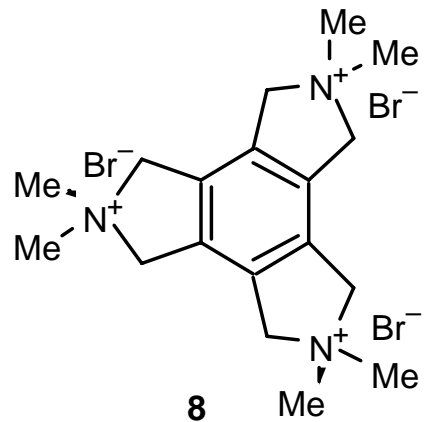<smiles>BrCc1c(CBr)c(CBr)c(CBr)c(CBr)c1CBr</smiles>

9

Reaction of 9 with an excess of pyrrolidine, piperidine and morpholine in boiling ethanol furnished, respectively, the salts 10, 11 and 12. Owing to their highly hygroscopic nature and their formation accompanied by the corresponding cyclic amine hydrobromides, difficulty was experienced in obtaining these in pure form, and only for $\mathbf{1 1}$ was it possible

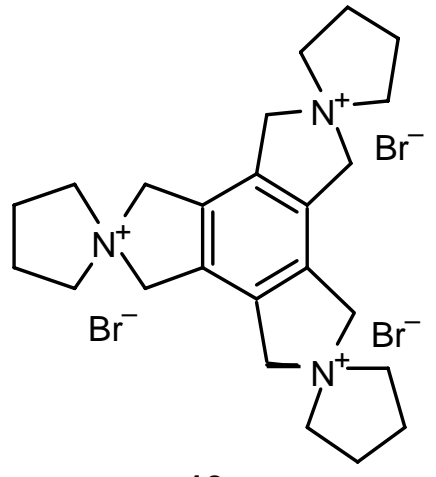

10

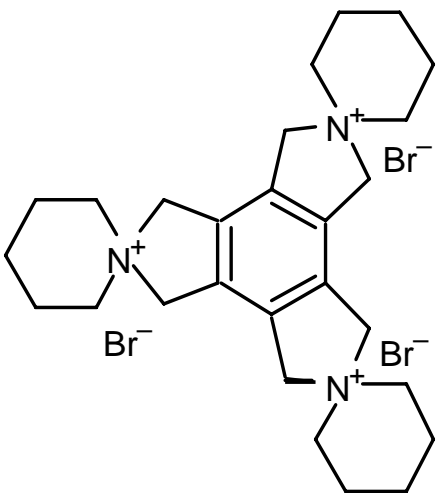

11

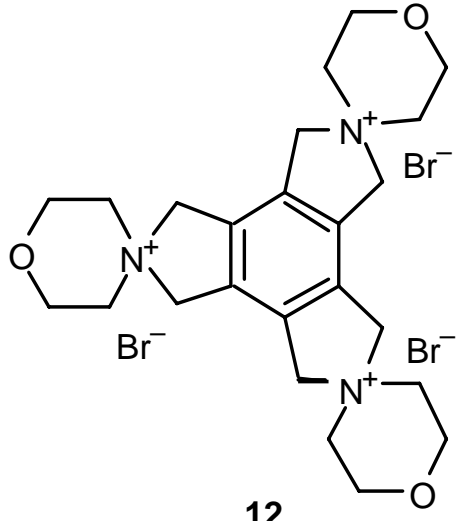

12

to produce an analytically pure sample (as the tetrahydrate). Nevertheless satisfactory ${ }^{1} \mathrm{H}$ and ${ }^{13} \mathrm{C}$ NMR data were obtained for all three compounds showing excellent agreement with the patterns already established for 3-6 and $\mathbf{7}$ although, unfortunately, the very similar chemical shift values observed for the various $\mathrm{N}^{+}-\mathrm{CH}_{2}$ and $\mathrm{O}-\mathrm{CH}_{2}$ groups precluded their unambiguous assignment. The application of these salts as templates for formation of new zeolite structures will be reported shortly.

\section{Experimental Section}

General Procedures. Melting points were determined using a Reichert hot-stage microscope and are uncorrected. Infrared spectra were recorded as nujol mulls on a Perkin Elmer 1420 instrument. NMR spectra were obtained for ${ }^{1} \mathrm{H}$ at $300 \mathrm{MHz}$ and for ${ }^{13} \mathrm{C}$ at $75 \mathrm{MHz}$ using a Bruker AM300 instrument. Spectra were run on solutions in $\mathrm{D}_{2} \mathrm{O}$ with internal 
$\mathrm{Me}_{3} \mathrm{Si}\left(\mathrm{CH}_{2}\right)_{3} \mathrm{SO}_{3}{ }^{-} \mathrm{Na}^{+}$as reference. Chemical shifts are reported in ppm to high frequency of the reference and coupling constants $J$ are in $\mathrm{Hz}$.

Hexa(bromomethyl)benzene (9) was prepared by the literature method involving addition of bromine to a solution of hexamethylbenzene in 1,2-dibromoethane with ultraviolet irradiation 6-Azoniaspiro[5.5] undecane bromide (3). A mixture of 1,5-dibromopentane (23 g, $0.1 \mathrm{~mol}$ ) and $\mathrm{NaOH}(4.0 \mathrm{~g}, 0.1 \mathrm{~mol})$ in water $\left(100 \mathrm{~cm}^{3}\right)$ was heated under reflux while piperidine $(8.5 \mathrm{~g}$, $0.1 \mathrm{~mol}$ ) was added dropwise over $30 \mathrm{~min}$. After heating for a further $30 \mathrm{~min}$, the mixture was cooled and an ice-cold soution of $\mathrm{NaOH}(20 \mathrm{~g})$ in water $\left(50 \mathrm{~cm}^{3}\right)$ was added. Partial evaporation of the resulting solution gave a colourless solid which was filtered off and recrystallised from ethanol to give the product $(16.0 \mathrm{~g}, 68 \%)$ as colourless crystals, mp $322^{\circ} \mathrm{C}\left(1 \mathrm{it} .{ }^{2} 311-312^{\circ} \mathrm{C}\right) ; \delta_{\mathrm{H}}$ $3.37(8 \mathrm{H}, \mathrm{t}, J \mathrm{7}), 1.85(8 \mathrm{H}, \mathrm{m})$ and $1.65(4 \mathrm{H}$, quintet, $J 7) ; \delta_{\mathrm{C}} 62.1\left(\mathrm{NCH}_{2}\right), 23.8$ $\left(\mathrm{NCH}_{2} \mathrm{CH}_{2} \mathrm{CH}_{2}\right)$ and $21.6\left(\mathrm{NCH}_{2} \mathrm{CH}_{2}\right)$.

5-Azoniaspiro[4.4]nonane bromide (4). A mixture of 1,4-dibromobutane (43.2 g,0.2 mol) and $\mathrm{NaOH}(8.0 \mathrm{~g}, 0.2 \mathrm{~mol})$ in water $\left(200 \mathrm{~cm}^{3}\right)$ was heated under reflux while pyrrolidine $(14.2 \mathrm{~g}$, $0.2 \mathrm{~mol}$ ) was added dropwise over $30 \mathrm{~min}$. After heating for a further $30 \mathrm{~min}$, the mixture was cooled and an ice-cold soution of $\mathrm{NaOH}(40 \mathrm{~g})$ in water $\left(100 \mathrm{~cm}^{3}\right)$ was added. Partial evaporation of the resulting mixture led to precipitation of the product as an oily solid. This was taken up in $\mathrm{CH}_{2} \mathrm{Cl}_{2}$ and precipitated by addition of diethyl ether. The resulting solid was filtered off and recrystallised from isopropanol to give the product $(17.7 \mathrm{~g}, 43 \%)$ as colourless crystals, mp 246-248 ${ }^{\circ} \mathrm{C}$ (lit., $\left.{ }^{2} 250-252^{\circ} \mathrm{C}\right) ; \delta_{\mathrm{H}} 3.54(8 \mathrm{H}, \mathrm{t}, \mathrm{J} 7)$ and $2.20(8 \mathrm{H}, \mathrm{m}) ; \delta_{\mathrm{C}} 65.4\left(\mathrm{NCH}_{2}\right)$ and $24.3\left(\mathrm{NCH}_{2} \mathrm{CH}_{2}\right)$.

5-Azoniaspiro[4.6]undecane bromide (5). A mixture of 1,6-dibromohexane (48.8 g,0.2 mol) and $\mathrm{NaOH}(8.0 \mathrm{~g}, 0.2 \mathrm{~mol})$ in water $\left(200 \mathrm{~cm}^{3}\right)$ was heated under reflux while pyrrolidine $(14.2 \mathrm{~g}$, $0.2 \mathrm{~mol}$ ) was added dropwise over $30 \mathrm{~min}$. After heating for a further $30 \mathrm{~min}$, the mixture was cooled and an ice-cold soution of $\mathrm{NaOH}(40 \mathrm{~g})$ in water $\left(100 \mathrm{~cm}^{3}\right)$ was added. This led to precipitation of the product as an oily solid which was filtered off and taken up in $\mathrm{CH}_{2} \mathrm{Cl}_{2}$. Drying and evaporation gave a yellow solid which was taken up in methanol and precipitated by addition to diethyl ether to give the product $(16.0 \mathrm{~g}, 34 \%)$ as yellow crystals, $\mathrm{mp} 255-258^{\circ} \mathrm{C}$ (lit., $\left.{ }^{2} 259-260^{\circ} \mathrm{C}\right) ; \delta_{\mathrm{H}} 3.50(4 \mathrm{H}, \mathrm{m}), 3.27(4 \mathrm{H}, \mathrm{m}), 2.18(4 \mathrm{H}, \mathrm{m}), 1.76(4 \mathrm{H}, \mathrm{m})$ and $1.42(4 \mathrm{H}$, $\mathrm{m}) ; \delta_{\mathrm{C}} 65.4,62.0,27.9,25.3$ and 24.1 .

8-Oxa-5-azoniaspiro[4.5]decane bromide (6). A mixture of 1,4-dibromobutane (21.6 $\mathrm{g}, 0.1 \mathrm{~mol})$ and $\mathrm{NaOH}(4.0 \mathrm{~g}, 0.1 \mathrm{~mol})$ in water $\left(100 \mathrm{~cm}^{3}\right)$ was heated under reflux while morpholine $(8.7 \mathrm{~g}, 0.1 \mathrm{~mol})$ was added dropwise over $30 \mathrm{~min}$. After heating for a further $30 \mathrm{~min}$, the mixture was cooled and an ice-cold soution of $\mathrm{NaOH}(20 \mathrm{~g})$ in water $\left(50 \mathrm{~cm}^{3}\right)$ was added. Partial evaporation of the resulting mixture led toprecipitation of the product as an oily solid. This was filtered off and recrystallised from isopropanol to give the product $(7.9 \mathrm{~g}, 36 \%)$ as colourless crystals, mp $193-196^{\circ} \mathrm{C}$ (lit., $\left.{ }^{2} 199-201^{\circ} \mathrm{C}\right) ; \delta_{\mathrm{H}} 4.06(4 \mathrm{H}, \mathrm{m}), 3.68(4 \mathrm{H}, \mathrm{m}), 3.54(4 \mathrm{H}$, $\mathrm{m})$ and $2.23(4 \mathrm{H}, \mathrm{m}) ; \delta_{\mathrm{C}} 65.8,64.7,61.7$ and 23.6 . 
6,9-Diazoniadispiro[5.2.5.2] hexadecane dibromide (7). A mixture of 1,5-dibromopentane $(46.0 \mathrm{~g}, 0.2 \mathrm{~mol})$ and $\mathrm{NaOH}(8.0 \mathrm{~g}, 0.2 \mathrm{~mol})$ in water $\left(200 \mathrm{~cm}^{3}\right)$ was heated under reflux while piperazine $(8.6 \mathrm{~g}, 0.1 \mathrm{~mol}$ ) was added dropwise over $30 \mathrm{~min}$. After heating for a further $30 \mathrm{~min}$, the mixture was cooled and an ice-cold soution of $\mathrm{NaOH}(20 \mathrm{~g})$ in water $\left(50 \mathrm{~cm}^{3}\right)$ was added. Partial evaporation of the resulting mixture led to precipitation of the product as an oily solid. This was filtered off, taken up in water and precipitated by addition to isopropanol to give the

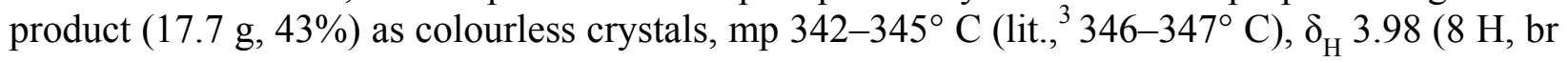
s), $3.69\left(8 \mathrm{H}, \mathrm{t}, J\right.$ 7), $1.93(8 \mathrm{H}, \mathrm{m})$ and $1.75\left(4 \mathrm{H}\right.$, quintet, $J$ 7); $\delta_{\mathrm{C}} 64.0(\mathrm{v} \mathrm{br}), 54.1$ $\left(\mathrm{NCH}_{2} \mathrm{CH}_{2} \mathrm{~N}\right), 23.3\left(\mathrm{NCH}_{2} \mathrm{CH}_{2} \mathrm{CH}_{2}\right)$ and $21.7\left(\mathrm{NCH}_{2} \mathrm{CH}_{2} \mathrm{CH}_{2}\right)$.

Benzotris[2,3](5-azoniaspiro[4.4]non-2-ene) tribromide (10). A mixture of hexa(bromomethyl)benzene $9(4.0 \mathrm{~g}, 6.3 \mathrm{mmol})$ and dry ethanol $\left(16 \mathrm{~cm}^{3}\right)$ was heated under reflux with vigorous stirring while pyrrolidine $(3.4 \mathrm{~g}, 50 \mathrm{mmol})$ was added dropwise. After the addition the mixture was heated under reflux for $5 \mathrm{~h}$ and cooled. The resulting solid was filtered off and washed well with ethanol to give the product $(1.70 \mathrm{~g}, 45 \%)$ as colourless crystals, mp 328$330^{\circ} \mathrm{C} ; v_{\max } / \mathrm{cm}^{-1} 1640,1320,1068,1045,1020,904$ and $720 ; \delta_{\mathrm{H}} 5.02(12 \mathrm{H}, \mathrm{s}), 3.81(12 \mathrm{H}, \mathrm{m})$ and $2.35(12 \mathrm{H}, \mathrm{m}) ; \delta_{\mathrm{C}} 132.9,68.1,67.3$ and 24.0.

Benzotris[2,3](5-azoniaspiro[4.5]dec-2-ene) tribromide (11). A mixture of hexa(bromomethyl)benzene $9(5.0 \mathrm{~g}, 7.9 \mathrm{mmol})$ and dry ethanol $\left(16 \mathrm{~cm}^{3}\right)$ was heated under reflux with vigorous stirring while piperidine $(4.25 \mathrm{~g}, 50 \mathrm{mmol})$ was added dropwise. After the addition the mixture was heated under reflux for $5 \mathrm{~h}$ and cooled. The resulting solid (piperidine hydrobromide) was filtered off and the filtrate evaporated. Extraction of the oily residue with $\mathrm{CH}_{2} \mathrm{Cl}_{2}$ led to precipitation of the product which was filtered off as colourless crystals $(3.1 \mathrm{~g}$, $60 \%$ ), mp 324-325 $5^{\circ}$ (Found: C, 45.0; H, 6.9; N,5.9. $\mathrm{C}_{27} \mathrm{H}_{42} \mathrm{Br}_{3} \mathrm{~N}_{3} \cdot 4 \mathrm{H}_{2} \mathrm{O}$ requires $\mathrm{C}, 45.0 ; \mathrm{H}$, $7.0 ; \mathrm{N}, 5.8 \%) ; v_{\max } / \mathrm{cm}^{-1} 1592,1070,1035,986,966,945,922,882,866$ and $724 ; \delta_{\mathrm{H}} 5.03(12 \mathrm{H}$, s), $3.68(12 \mathrm{H}, \mathrm{t}, J \mathrm{~J}), 2.00(12 \mathrm{H}, \mathrm{m})$ and $1.76(6 \mathrm{H}, \mathrm{m}) ; \delta_{\mathrm{C}} 132.4,68.5,64.8,23.8(6 \mathrm{C})$ and 23.0(3 C).

Benzotris[2,3](8-oxa-5-azoniaspiro[4.5]dec-2-ene) tribromide (12). A mixture of hexa(bromomethyl)benzene $9(5.0 \mathrm{~g}, 7.9 \mathrm{mmol})$ and dry ethanol $\left(16 \mathrm{~cm}^{3}\right)$ was heated under reflux with vigorous stirring while morpholine $(4.35 \mathrm{~g}, 50 \mathrm{mmol})$ was added dropwise. After the addition the mixture was heated under reflux for $11 \mathrm{~h}$ and cooled. The resulting solid was filtered off taken up in methanol which led to precipitation of the product $(3.3 \mathrm{~g}, 64 \%)$ as colourless crystals still containing some morpholine hydrobromide; $\delta_{\mathrm{H}} 5.17(12 \mathrm{H}, \mathrm{s}), 4.15(12 \mathrm{H}, \mathrm{m})$ and $3.76(12 \mathrm{H}, \mathrm{m}) ; \delta_{\mathrm{C}} 136.4,69.3,64.5$ and 62.5 .

\section{Variable temperature NMR study}

A solution of salt 7 in $\mathrm{D}_{2} \mathrm{O} / \mathrm{CD}_{3} \mathrm{OD}(2: 1)$ was used to obtain spectra over the range $-20{ }^{\circ} \mathrm{C}$ to $+50^{\circ} \mathrm{C}$. The spectra at the ends of this range were as follows: $+50^{\circ} \mathrm{C}-\delta_{\mathrm{C}} 62.1(4 \mathrm{C}, \mathrm{br}), 52.8(4$ 
C), 21.9 (2 C) and $20.3(4 \mathrm{C}) ;-20^{\circ} \mathrm{C}-\delta_{\mathrm{C}} 66.85$ (2 C), 56.67 (2 C), 52.5 (4 C, br), 22.2 (2 C) and $20.5(4 \mathrm{C})$. Low temperature $\Delta v=768.26 \mathrm{~Hz}$. The probe temperature at the coalescence point was checked by means of a digital thermometer and found to be $19 \pm 1^{\circ} \mathrm{C}(292 \mathrm{~K})$. Using the formula $\Delta \mathrm{G}^{\#}=\mathrm{RT}_{\mathrm{C}}\left[22.96+\ln \left(\mathrm{T}_{\mathrm{c}} / \Delta v\right)\right]$ gives a value of $53.4 \pm 0.2 \mathrm{~kJ} \mathrm{~mol}^{-1}$.

\section{Solid-state CP-MAS NMR study}

${ }^{13} \mathrm{C} \mathrm{CP} / \mathrm{MAS}$ spectra of 7 at ambient temperature were obtained at $125.758 \mathrm{MHz}$ on a Bruker MSL500 spectrometer in $4 \mathrm{~mm}$ o.d. zirconia rotors at a spinning speed of ca $6 \mathrm{kHz}$. $\delta_{\mathrm{C}} 62.4(2$ C), 55.6 (4 C), 47.6 (2 C), 23.9 (2 C), 21.2 (2 C) and 20.0 (2 C).

\section{References and Notes}

1. Patinec, V.; Wright, P. A.; Aitken, R. A.; Lightfoot, P.; Purdie, S. D. J.; Cox, P. A.; Kvick, A.; Vaughan, G. Chem. Mater. 1999, 2456.

2. Blicke, F. F.; Hotelling, E. B.J. Am. Chem. Soc. 1954, 76, 5099.

3. Blicke, F. F.; Hotelling, E. B. J. Am. Chem. Soc.1954, 76, 2427.

4. Prescher, D.; Engler, G.; Blume, A.; Platonov, V. E.; Osina, O. I. Z. Chem. 1989, 29, 340.

5. Abraham, R. J.; MacDonald, D.B. Chem. Commun. 1966, 188.

6. Murray, R. W.; Kaplan, M. L. Tetrahedron 1969, 25, 1651.

7. Ciric, J.; Lawton, S. L.; Kokotailo, G. T.; Griffin, G. W. J. Am. Chem. Soc. 1978, 100, 2173.

8. Lawton, S. L.; Rohrbaugh, W. J. Science 1990, 247, 1319. 